\title{
Analisis Pengaruh Karakteristik Individu, Pekerjaan dan Lingkungan Kerja Terhadap Motivasi dan Kinerja Tenaga Kerja Sukarela Pengumpul Sampah
}

\author{
(Studi Pada Dinas Lingkungan Hidup Kabupaten Rejang Lebong)
}

\author{
Anita Melina Febriyanti ${ }^{1}$, Ginta Ginting ${ }^{2}$, Andriyansah $^{3}$ \\ Mahasiswa Program Magister Manajemen Universitas Terbuka ${ }^{1}$ \\ Dosen Universitas Terbuka ${ }^{2,3}$ \\ anitafebrialina12@gmail.com \\ ginta@ecampus.ut.ac.id \\ andri@ecampus.ut.ac.id
}

\begin{abstract}
ABSTRAK
Dinas Lingkungan Hidup Kabupaten Rejang Lebong merupakan salah satu Instansi Pemerintah yang memiliki aset berupa tenaga kerja sukarela sebanyak 277 orang pada tahun 2020, dengan tenaga kerja sukarela pengumpul sampah berjumlah 80 orang. Sumber daya manusia atau tenaga kerja sukarela tersebut ikut andil dan berperan penting dalam keberhasilan dan tercapainya tujuan instansi dalam hal ini Dinas Lingkungan Hidup Kabupaten Rejang Lebong. Berdasarkan data dari Bagian Persampahan dan Limbah B3 Dinas Lingkungan Hidup Kabupaten Rejang Lebong pada tahun 2017, 2018, dan 2019, tenaga kerja sukarela pengumpul sampah mampu mengumpulkan sampah secara berturut-turut sebanyak 14.999,82 ton, $15.191,71$ ton, dan $16.230,88$ ton atau hanya sebesar $39,68 \%, 40,03 \%$, dan 42,65\% dari target yang direncanakan oleh pihak Dinas Lingkungan Hidup Kabupaten Rejang Lebong untuk tahun 2017, 2018, dan 2019 secara berturut-turut sebesar 37.800 ton, 37.951,97 ton, dan 38.103,78 ton. Hal tersebut menunjukan bahwa target yang tercapai untuk tahun 2017, 2018, dan 2019 masih kurang dari 50\%. Berdasarkan hasil penelitian yang dilakukan dapat diketahui terdapat beberapa hal yang mempengaruhi motivasi dan kinerja tenaga kerja dalam mencapai tujuan instansi, diantaranya yaitu: karakteristik pekerjaan mempengaruhi motivasi, dan karakteristik individu, lingkungan kerja, serta motivasi mempengaruhi kinerja tenaga kerja.
\end{abstract}

Kata Kunci : Kinerja, Karakteristik Individu, Karakteristik Pekerjaan, Lingkungan Kerja, Motivasi.

\begin{abstract}
The Environmental Agency of Rejang Lebong Regency is one of the Government Agencies that has assets of 277 volunteers in 2020, with 80 voluntary garbage collection workers. Human resources or voluntary workforce contribute and have an important role in the success and achievement of the agency's goals in this case the Rejang Lebong Environmental Agency. Based on data from The Hazardous and Non-Hazardous Waste Section in Rejang Lebong Environmental Agency in 2017, 2018 and 2019, the voluntary workforce of garbage collectors are able to collect waste as many as 14,999.82 tons, $15,191.71$ tons and 16,230.88 tons tons or only $39.68 \%, 40.03 \%$, and $42.65 \%$ of the targets planned by the Rejang Lebong Environmental Agency for 2017, 2018 and 2019 respectively 37,800 tons, 37,951.97 tons, and 38,103.78 tons. This shows that the targets achieved for 2017, 2018 and 2019 are still less than 50\%. Based on the results of this research, it can be seen that there are several things that affect the motivation and performance of workers in achieving agency goals, including: job characteristics affect motivation, and individual characteristics, work environment, and motivation affect workforce performance.
\end{abstract}

Keywords: Individual Characteristics, Job Characteristics, Motivation, Performance, Work Environment

\section{PENDAHULUAN}

Dinas Lingkungan Hidup Kabupaten Rejang Lebong merupakan salah satu Instansi Pemerintah yang memiliki aset berupa tenaga kerja sukarela. Berdasarkan data dari Bagian Kepegawaian Dinas Lingkungan Hidup Kabupaten Rejang Lebong, jumlah tenaga kerja sukarela di Dinas Lingkungan Hidup Kabupaten Rejang Lebong pada tahun 2020 sebanyak 277 orang, dengan tenaga kerja sukarela pengumpul sampah berjumlah 80 orang. Sumber daya manusia atau tenaga kerja sukarela tersebut ikut andil dan berperan penting dalam keberhasilan dan tercapainya tujuan instansi dalam hal ini Dinas Lingkungan Hidup Kabupaten Rejang Lebong.

Berdasarkan data dari Bagian Persampahan dan Limbah B3 Dinas Lingkungan Hidup Kabupaten 
Rejang Lebong pada tahun 2017, 2018, dan 2019, tenaga kerja sukarela pengumpul sampah mampu mengumpulkan sampah secara berturut-turut sebanyak $14.999,82$ ton, $15.191,71$ ton, dan $16.230,88$ ton atau hanya sebesar $39,68 \%, 40,03 \%$, dan $42,65 \%$ dari target yang direncanakan oleh pihak Dinas Lingkungan Hidup Kabupaten Rejang Lebong untuk tahun 2017, 2018, dan 2019 secara berturut-turut sebesar 37.800 ton, 37.951,97 ton, dan $38.103,78$ ton. Hal tersebut menunjukan bahwa target yang tercapai untuk tahun 2017, 2018, dan 2019 masih kurang dari 50\%. Hal tersebut menunjukan bahwa tujuan instansi belum dapat tercapai dengan maksimal, yang artinya sampah yang dihasilkan masyarakat setiap harinya belum dapat tertangani secara keseluruhan karena kemampuan tenaga kerja pengumpul sampah dalam mengumpulkan sampah berdasarkan data yangn ada belum maksimal.

Dinas Lingkungan Hidup Kabupaten Rejang Lebong selaku pemilik aset berupa sumber daya manusia atau tenaga kerja sukarela pengumpul sampah tersebut selalu berusaha meningkatkan kualitas sumber dayanya secara optimal agar dapat bekerja lebih maksimal lagi. Untuk itu diperlukan manajemen sumber daya manusia untuk meningkatkan produktivitas instansi yang bersangkutan (Kurniawati, 2014).

Suatu instansi harus memperlakukan tenaga kerja secara adil dan dengan sebaik-baiknya, sehingga dapat menumbuhkan sikap loyalitas dari mereka kepada Instansi itu sendiri (Sunuharyo dan Ananda, 2018). Begitu pula yang hendaknya dilakukan Dinas Lingkungan Hidup Kabupaten Rejang Lebong kepada para tenaga kerja sukarela pengumpul sampah. Selain itu, karakteristik individu dari masing-masing tenaga kerja sukarela pengakut sampah juga harus diketahui dan dipahami oleh Dinas Lingkungan Hidup Kabupaten Rejang Lebong agar dapat memberikan motivasi kepada mereka dengan tepat sehingga membuat mereka semakin terpacu untuk meningkatkan kontribusi dan kinerjanya kepada instansi. Karakteristik individu itu sendiri terdiri dari minat, sikap dan kebutuhan yang dibawa seseroang kedalam situasi kerja dan dipengaruhi oleh beberapa hal diantaranya: usia, jenis kelamin, status perkawinan, jumlah tanggungan, dan pengalaman kerja (Hayati dan Imelda, 2014). Berdasarkan data dari Bagian Kepegawaian Dinas Lingkungan Hidup Kabupaten Rejang Lebong, 2\% dari total tenaga kerja sukarela pengumpul sampah berusia dibawah 20 tahun dan sebesar 19\% berusia diatas 50 tahun. Hal tersebut dapat mempengaruhi karakteristik individu mereka berupa kemampuan dalam menjalankan atau melaksanakan tugas, mengingat pekerjaan mengumpulkan sampah merupakan pekerjaan yang mengandalkan kemampuan fisik.
Selain karakteristik individu, karakteristik pekerjaan juga menjadi unsur yang mempengaruhi motivasi dan kinerja tenaga kerja sukarela pengumpul sampah. Karakteristik pekerjaan tersebut meliputi besarnya tanggungjawab, variasi tugas, dan sejauh mana pekerjaan itu dapat memberikan suatu kepuasan. Pada dasarnya pekerjaan yang dapat memberikan kepuasan akan lebih memotivasi banyak orang dalam bekerja dari pada pekerjaan yang tidak memberikan kepuasan sama sekali (Stoner dan Freeman, 1994). Selain itu, pada kenyataannya pekerjaan mengumpulkan sampah termasuk kedalam jenis pekerjaan yang monoton atau tidak bervariasi. Hal tersebut juga dapat mempengaruhi motivasi dan kinerja tenaga kerja dalam bekerja.

Variabel lain yang ikut serta mempengaruhi motivasi dan kinerja tenaga kerja sukarela pengumpul sampah adalah lingkungan kerja. Keadaan lingkungan kerja yang nyaman, aman dan mendukung akan mempengaruhi motivasi dan kinerja tenaga kerja dalam melakukan tugasnya. Hal ini dapat memberi pengaruh positif bagi kondisi psikologis tenaga kerja. Sedangkan pada kenyataannya pekerjaan mengumpulkan sampah identik dengan lingkungan kerja yang penuh dengan risiko, mulai dari kondisi yang lembab sehingga memungkinkan bakteri dapat berkembang dengan cepat, sirkulasi udara yang buruk karena udara disekitar tempat kerja sudah terkontaminsi zat berbahaya yang bersumber dari sampah, dan lainlain. Hal tersebut dapat membahayakan kesehatan tenaga kerja, selain itu juga dapat mempengaruhi motivasi dan kinerja tenaga kerja mengingat lingkungan kerja yang penuh dengan risiko.

Berdasarkan uraian diatas, maka penulis tertarik untuk melakukan penelitian terkait pengaruh karakteristik individu, pekerjaan, dan lingkungan kerja terhadap motivasi dan dampaknya terhadap kinerja tenaga kerja sukarela pengumpul sampah di Dinas Lingkungan Hidup Kabupaten Rejang Lebong.

\section{METODE PENELITIAN}

\section{Jenis Penelitian}

Penelitian ini menggunakan penelitian deskriptif dengan pendekatan kuantitatif. Dimana maksud dari penelitian deskriptif dengan pendekatan kuantitatif yakni penelitian ini dilakukan dengan menghitung dan menganalisa frekuensi item dari variabel pertanyaan responden yang kemudian dianalisa berdasarkan perhitungan angka-angka menggunakan statistik (Andriyansah, 2019), untuk mendapatkan gambaran mengenai pengaruh masing-masing variabel terhadap kinerja tenaga kerja sukarela pengumpul sampah di Dinas Lingkungan Hidup Kabupaten Rejang Lebong. 


\section{Prosedur Pengumpulan Data}

Data jumlah responden sebagai sampel sebanyak 130 responden. Namun peneliti tidak mengambil sampel sesuai yang dipersyaratkan karena jumlah tenaga kerja sukarela pengumpul sampah di Dinas Lingkungan Hidup Kabupaten Rejang Lebong tidak mencukupi, hanya sebanyak 80 orang. Sesuai dengan salah satu kelebihan alat analisis SmartPLS batas sampel yang dipersyaratkan yakni 30-100. Dengan demikian persyaratan pengambilan sampel pada Dinas Lingkungan Hidup sesuai dengan persyaratan di Dinas Lingkungan Hidup Kabupaten Rejang Lebong. Untuk diagram kerangka berpikir dapat dilihat sebagai berikut:

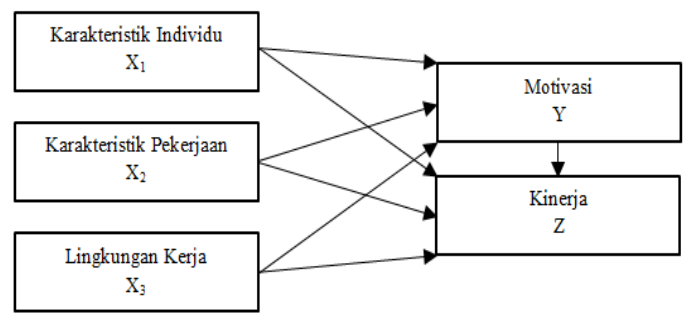

Diagram 1. Kerangka Berpikir

\section{Instrumen Penelitian}

Teknik pengumpulan data yang dilakukan dalam penelitian ini adalah dengan menggunakan kuesioner. Digunakan untuk mendapatkan data mengenai dimensi-dimensi dari variabel-variabel yang dianalisis dengan lima alternative nomor untuk mengukur sikap responden. Skala 1-5 digunakan pada pertanyaan-pertanyaan untuk mendapatkan data yang bersifat interval dan diberi skor atau nilai.

\section{Metode Analisis Data}

Analisis data pada penelitian ini dilakukan data penelitian yang diperoleh dari studi langsung, kuesioner, wawancara dan studi dokumentasi selanjutnya dianalisis dengan menggunakan analisis desktiptif dan model persamaan struktural (Structural Equation Modeling - SEM) dengan menggunakan program Partial Least Structural (PLS) dan bantuan Statistical Program for Social Sciances (SPSS). Untuk penolakan atau penerimaan hipotesis, digunakan taraf signifikansi $\mathrm{P}<0,05$. SPPS digunakan untuk menghitung validitas dan realibilitas dari instrument penelitian.

\section{Analisis Deskriptif}

Analisis yang berkaitan dengan pengumpulan data dan penyajian sekelompok data guna memperoleh informasi. Analisis ini digunakan dengan cara menabulasi hasil kuesioner secara manual guna mengetahui karakteristik responden berdasarkan usia, jenis kelamin, jabatan, pendidikan terakhir, masa kerja, status perkawinan, dan pendapatan. proporsi jawaban responden terhadap berbagai pilihan jawaban yang mendeskripsikan tentang faktor-faktor yang mempengaruhi karakteristik individu, karakteristik pekerjaan, lingkungan kerja, motivasi dan kinerja yang dituangkan dalam butir-butir pernyataan yang tersedia dalam kuesioner.

\section{Analisis SEM dengan PLS}

Analisis pada penelitian ini menggunakan model Structural Equation Model (SEM) dengan Partial Least Structural (PLS). SEM digunakan karena pada penelitian ini menganalisis hubungan antar variabel secara langsung maupun tidak langsung dengan variabel intervening. Variabel intervening merupakaan variabel perantara, yaitu motivasi.

\section{Model Struktural atau Inner Model}

Pada Model Inner model menggambarkan hubungan antara variabel laten, hal tersebut berdasarkan teori substansif. R-square mengevalusi model struktural untuk kontruk dependen. Penilaian terhadap model menggunakan Patrial Least Square (PLS) dimulai dengan melihat R-square untuk setiap variabel laten dependen. Interpretasi nya sama dengan interpretasi regresi. Perubahan yang terjadi pada nilai R-square digunakan untuk melihat variabel laten independen tertentu terhadap variabel laten dependen.

\section{Model Pengukuran atau Outer Model}

Pada Model Outer model menganalisis hubungan antara variabel laten dan indikator. Convergent validity dari model pengukuran dengan model refleksi indikator dinilai berdasarkan hubungan antara item score/component score dengen conturct score yang dihitung menggunkan Patrial Least Square (PLS) dan dikatakan tinggi jika kolerasi lebih dari 0,70 . Untuk penelitian tahap awal dari pengembangan skala pengukuran nilai loading dianggap cukup yakni antara 0,5 sampai 0,60. Jika korelasi variabel laten dengan item pengukuran lebih besar daripada variabel laten lainnya, maka discriminant validity dinilai berdasarkan cross loading. Selain itu discriminant validity juga dapat dinilai dengan membandingkan nilai square root of Average Variance Extracted (AVE). jika nilai akar dari Average Variance Extracted $(A V E)$ variabel laten lebih besar dari pada nilai korelasi antara variabel laten dengan variabel laten lainnya dalam model, maka nilai discriminant validity dapat dikatakan baik. Pengukuruan ini hasilnya lebih konservatif dibandingkan dengan composite realibility 
dengan rekomendasi nilai Average Variance Extracted (AVE) harus lebih besar dari 0,50. Composite reability yang mengukur variabel laten dapat dievaluasi dengan internal consistency dan crinbach's alpha dengan nilai yang diharapkan lebih dari 0,6 untuk semua variabel (Ghozali, 2008).

\section{HASIL PENELITIAN DAN PEMBAHASAN}

\section{Hasil Analisis Partial Least Square (PLS)}

Pengaruh Karakteristik Individu, Pekerjaan, dan Lingkungan Kerja terhadap Motivasi dan Kinerha Tenaga Kerja Pengumpul Sampah di Dinas Lingkungan Hidup Kabupaten Rejang Lebong

Metode analisa yang dilakukan untuk mengetahui bentuk dan besar pengaruh variabel karakteristik individu, karakteristik pekerjaan, dan lingkungan kerja terhadap variabel motivasi dan variabel kinerja tenaga kerja adalah menggunakan Partial Least Square (PLS) yang diolah dengan SmartPLS 3.0. hasil analisis model penelitian dapat dilihat sebagai berikut:

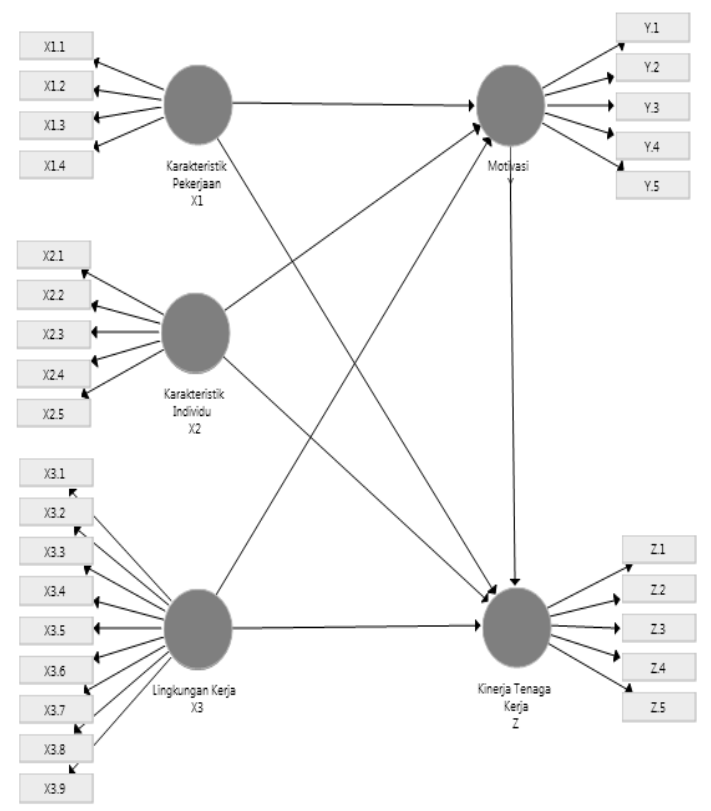

Gambar 6. Model Pengaruh Karakteristik Individu, Pekerjaan, dan Lingkungan Kerja Terhadap Motivasi dan Kinerja Tenaga Kerja Pengumpul Sampah di Dinas Lingkungan Hidup Kabupaten Rejang Lebong

Dari hasil di atas terdapat bentuk hubungan antara variabel laten dengan indikator, yaitu hubungan reflektif. Variabel karakteristik individu direfleksikan dengan kemampuan (X1.1), nilai (X1.2), sikap (X1.3), minat (X1.4). Variabel karakteristik pekerjaan direfleksikan dengan umpan balik (X2.1), arti tugas (X2.2), otonomi (X2.3), keanekaragaman keterampilan (X2.4), identitas tugas (X2.5). Variabel lingkungan kerja direfleksikan dengan sirkulasi udara (X3.1), bau (X3.2), temperatur (X3.3), getaran (X3.4), kebisingan (X3.5), kelembaban (X3.6), cahaya (X3.7), hubungan tenaga kerja dengan atasan (X3.8), hubungan antar tenaga kerja (X3.9). variabel motivasi direfleksikan dengan prestasi (Y1), pengakuan (Y2), minat pada pekerjaan (Y3), tanggung jawab (Y4), kemajuan (Y5). Variabel kinerja direfleksikan dengan tanggung jawab (Z1), waktu kerja (Z2), kerjasama (Z3), kualitas kerja (Z4), kuantitaas kerja (Z5). Setelah model dibentuk dengan menggunakan software SmartPLS 3.0, dilakukan pengujian kelayakan model.

\section{Evaluasi Outer Model - Reflektif}

Hubungan antar variabel yang terdapat dalam penelitian ini berbentuk reflektif. Menurut Ghozaly (2008) bahwa terdapat 4 (empat) kriteria untuk mengevaluasi outer model - reflektif, diantaranya yaitu Convergent Validity, Descriminat Validity, Average Variance Extracted (AVE) dan Composite Reliability. Kriteria tersebut secara lengkap dapat dilihat sebagai berikut:

Tabel 1. Kriteria dan Standarisasi dalam Evaluasi Outer Model - Reflektif

\begin{tabular}{|c|c|c|}
\hline Kriteria & Standar & Keterangan \\
\hline $\begin{array}{l}\text { Convergent } \\
\text { Validity }\end{array}$ & Nilai loading $>0,5$ & $\begin{array}{l}\text { Menilai kekuatan } \\
\text { indikator dalam } \\
\text { merefleksikan } \\
\text { variabel laten, } \\
\text { jika < } 0,5 \text { maka } \\
\text { indikator harus di } \\
\text { drop. }\end{array}$ \\
\hline $\begin{array}{l}\text { Descriminat } \\
\text { Validity }\end{array}$ & $\begin{array}{l}\text { Nilai cross loading, } \\
\text { korelasi indikator } \\
\text { ke variabel latennya } \\
\text { lebih besar dari } \\
\text { variabel laten lain. }\end{array}$ & $\begin{array}{l}\text { Mengukur } \\
\text { ketepatan model } \\
\text { refleksi. }\end{array}$ \\
\hline $\begin{array}{l}\text { Average } \\
\text { Variance } \\
\text { Extracted } \\
(A V E)\end{array}$ & AVE $>0,5$ & $\begin{array}{l}\text { Mengukur } \\
\text { konsistensi } \\
\text { indikator dalam } \\
\text { mengukur } \\
\text { variabel laten. }\end{array}$ \\
\hline $\begin{array}{l}\text { Composite } \\
\text { Reliability } \\
\left(\rho_{\mathrm{c}}\right)\end{array}$ & $\left(\rho_{c}\right)>0,6$ & $\begin{array}{l}\text { Kestabilan dan } \\
\text { konsistensi } \\
\text { internal indikator } \\
\text { yang baik. }\end{array}$ \\
\hline
\end{tabular}

Sumber: Ghazali (2005)

\section{Convergent Validity}

Convergent validity atau reliabilitas indikator dicerminkan dari nilai loading factor yang merefleksikan kekuatan interlasi antar variabel laten karakteristik individu, karakteristik pekerjaan, lingkungan kerja, motivasi, dan kinerja tenaga kerja terhadap masing-masing variabel indikatornya. Pada Tabel 4.2 dapat dilihat bahwa kemampuan fisik (X1.1) merefleksikan interelasi terbesar dalam menggambarkan karakteristik individu dengan nilai loading factor sebesar 0,963, menyelesaikan pekerjaan sesuai dengan rencana (Z5) merefleksikan interelasi terbesar dalam 
menggambarkan kinerja tenaga kerja dengan nilai loading factor sebesar 0,910, kejelasan tugas yang harus diselesaikan secara menyeluruh (X2.5) merefleksikan interelasi terbesar dalam menggambarkan karakteristik pekerjaan dengan nilai loading factor sebesar 0,884 , minat kerja yang tinggi (Y5) merefleksikan interelasi terbesar dalam menggambarkan motivasi dengan nilai loading factor sebesar 0,876, hubungan dengan rekan kerja (X3.8) merefleksikan interelasi terbesar dalam menggambarkan lingkungan kerja dengan nilai loading factor sebesar 0,839 .

Tabel 2. Nilai Loading Factor pada Variabel Laten Karakteristik Individu, Karakteristik Pekerjaan, Lingkungan Kerja, Motivasi dan Kinerja Tenaga Kerja Sukarela Pengumpul Sampah

\begin{tabular}{|c|c|c|c|c|c|}
\hline & $\begin{array}{l}\text { Karakteristik } \\
\text { Individu } \\
\text { (X1) }\end{array}$ & $\begin{array}{c}\text { Karakteristik } \\
\text { Pelkerjaan } \\
\text { (X2) }\end{array}$ & $\begin{array}{c}\text { Kinerja } \\
\text { Tenaga } \\
\text { Kerja } \\
\text { (Z) }\end{array}$ & $\begin{array}{c}\text { Lingkungan } \\
\text { Kerja } \\
\text { (X3) }\end{array}$ & $\begin{array}{l}\text { Motivasi } \\
\text { (Y) }\end{array}$ \\
\hline $\mathrm{X} 1.1$ & 0,963 & 0,216 & 0,735 & 0,639 & 0,360 \\
\hline $\mathrm{X} 1.2$ & 0,923 & 0,236 & 0,671 & 0,693 & 0,348 \\
\hline $\mathrm{X} 1.3$ & 0,868 & 0,216 & 0,735 & 0,527 & 0,458 \\
\hline $\mathrm{X} 1.4$ & 0,950 & 0,183 & 0,827 & 0,772 & 0,480 \\
\hline $\mathrm{X} 2.1$ & 0,208 & 0,787 & 0,155 & 0,241 & 0,333 \\
\hline $\mathrm{X} 2.2$ & 0,104 & 0,881 & 0,205 & 0,286 & 0,478 \\
\hline $\mathrm{X} 2.3$ & 0,073 & 0,826 & 0,234 & 0,301 & 0,410 \\
\hline $\mathrm{X} 2.4$ & 0,336 & 0,806 & 0,280 & 0,288 & 0,513 \\
\hline $\mathrm{X} 2.5$ & 0,208 & 0,884 & 0,337 & 0,370 & 0,730 \\
\hline $\mathrm{X} 3.1$ & 0,153 & 0,304 & 0,313 & 0,718 & 0,307 \\
\hline $\mathrm{X} 3.2$ & 0,207 & 0,326 & 0,365 & 0,730 & 0,263 \\
\hline $\mathrm{X} 3.3$ & 0,207 & 0,326 & 0,365 & 0,730 & 0,263 \\
\hline $\mathrm{X} 3.4$ & 0,166 & 0,315 & 0,335 & 0,737 & 0,323 \\
\hline $\mathrm{X} 3.5$ & 0,196 & 0,340 & 0,366 & 0,736 & 0,359 \\
\hline X3.6 & 0,181 & 0,327 & 0,342 & 0,739 & 0,341 \\
\hline $\mathrm{X} 3.7$ & 0,524 & 0,256 & 0,720 & 0,713 & 0,404 \\
\hline $\mathrm{X} 3.8$ & 0,813 & 0,312 & 0,858 & 0,839 & 0,623 \\
\hline $\mathrm{X} 3.9$ & 0,746 & 0,156 & 0,761 & 0,763 & 0,422 \\
\hline Y1 & 0,861 & 0,295 & 0,915 & 0,878 & 0,628 \\
\hline $\mathrm{Y} 2$ & 0,687 & 0,353 & 0,853 & 0,738 & 0,746 \\
\hline $\mathrm{Y} 3$ & 0,188 & 0,407 & 0,299 & 0,295 & 0,836 \\
\hline Y4 & 0,208 & 0,884 & 0,337 & 0,370 & 0,730 \\
\hline Y5 & 0,232 & 0,378 & 0,383 & 0,381 & 0,876 \\
\hline $\mathrm{zl}$ & 0,603 & 0,242 & 0,879 & 0,634 & 0,533 \\
\hline $\mathrm{z} 2$ & 0,582 & 0,286 & 0,787 & 0,727 & 0,456 \\
\hline $\mathrm{z} 3$ & 0,843 & 0,198 & 0,826 & 0,768 & 0,423 \\
\hline $\mathrm{Z} 4$ & 0,627 & 0,253 & 0,898 & 0,636 & 0,555 \\
\hline Z5 & 0,768 & 0,331 & 0,910 & 0,768 & 0,702 \\
\hline
\end{tabular}

Sumber: hasil data primer yang diolah SmartPLS 3.0, 2020

\section{Descriminat Validity}

Tabel 2. menunjukkan nilai korelasi variabel karakteristik individu, karakteristik pekerjaan, lingkungan kerja, motivasi, dan kinerja tenaga kerja dengan masing-masing indikatornya. Jika indikatorindikator pada karakteristik individu memang menggambarkan refleksi dari karakteristik individu, maka nilai korelasi dari indikator-indikator terhadap karakteristik individu tersebut haruslah lebih besar dari pada korelasi indikator-indikator tersebut terhadap variabel laten lainnya. Tabel 2 . menunjukkn bahwa nilai korelasi terhadap karakteristik individu lebih besar dari pada korelasi indikator yang sama terhadap variabel laten lainnya. Hal tersebut membuktikan bahwa model reflektif karakteristik individu pada penelitian ini adalah valid. Begitu juga untuk variabel-variabel lainnya.

\section{Average Variance Extracted (AVE)}

Validitas menunjukkan bahwa suatu pengujian benar-benar konsisten mengukur apa yang seharusnya diukur, dalam hal ini bagaimana indikator-indikator (baik karakteristik individu, karakteristik pekerjaan, lingkungan kerja, motivasi, dan kinerja tenaga kerja) konsisten mengukur masing-maisng variabel latennya. Hal ini dapat digambarkan dalam besaran nilai Average Variance Extracted ( $A V E)$. Nilai $A V E$ untuk penelitian ini dapat dilihat pada Tabel 3. Tabel tersebut menunjukkan bahwa nilai $A V E$ untuk tiap variabel adalah di atas standar, berarti baik indikator karakteristik individu, karakteristik pekerjaan, lingkungan kerja, motivasi, dan kinerja tenaga kerja konsisten dalam mengukur variabel-variabel latennya.

Tabel 3. Nilai $A V E$ Karakteristik Individu, Karakteristik Pekerjaan, Lingkungan Kerja, Motivasi, dan Kinerja Tenaga Kerja Pengumpul Sampah

\begin{tabular}{clc}
\hline No. & \multicolumn{1}{c}{ Variabel } & $\begin{array}{c}\text { Average Variance } \\
\text { Extracted }(\boldsymbol{A V E})\end{array}$ \\
\hline 1 & Karakteristik Individu & 0,859 \\
2 & Karakteristik Pekerjaan & 0,702 \\
3 & Kinerja Tenaga Kerja & 0,742 \\
4 & Lingkungan Kerja & 0,583 \\
5 & Motivasi & 0,651
\end{tabular}

Sumber: hasil data primer yang diolah oleh SmartPLS 3.0, 2020.

\section{Composite Reliability}

Nilai composite reliability dapat dilihat pada nilai outer model loading variabel laten masing-masing. Composite reliability, baik karakteristik individu, karakteristik pekerjaan, lingkungan kerja, motivasi, dan kinerja tenaga kerja memiliki nilai $\rho_{c}>0,6$ dapat dilihat pada tabel di bawah nilai yang dihasilkan menunjukkan kestabilan dan konsistensi internal indikator yang baik. 


\begin{tabular}{|c|c|c|}
\hline No. & Variabel & $\begin{array}{l}\text { Composite } \\
\text { Reliability }\end{array}$ \\
\hline 1 & Karakteristik Individu & 0,96 \\
\hline 2 & Karakteristik Pekerjaan & 0,921 \\
\hline 3 & Kinerja Tenaga Kerja & 0,935 \\
\hline 4 & Lingkungan Kerja & 0,926 \\
\hline 5 & Motivasi & 0,903 \\
\hline
\end{tabular}

Sumber: hasil data primer yang diolah oleh SmartPLS 3.0, 2020.

\section{Evaluasi Inner Model}

Inner model dievaluasi dengan menggunakan $R$ Square untuk variabel endogen dan membandingkan $t_{\text {hitung }}$ dengan $t_{\text {tabel }}\left(t_{\text {tabel }}\right.$ dengan tingkat kepercayaan 95\% adalah 1,96). Penelitian ini memiliki 5 (lima) variabel yaitu karakteristik individu, karakteristik pekerjaan, lingkungan kerja, motivasi, dan kinerja tenaga kerja. Variabel kinerja tenaga kerja dipengaruhi oleh variabel karakteristik individu, karakteristik pekerjaan, dan lingkungan kerja, sedangkan variabel motivasi merupakan variabel intervening yang mempengaruhi kinerja. Nilai $R$-Square dapat dilihat sebagai berikut:

Tabel 5. Nilai R-Square Variabel Karakteristik Individu, Karakteristik Pekerjaan, Lingkungan Kerja, Motivasi, dan Kinerja Tenaga Kerja Pengumpul Sampah

\begin{tabular}{clc}
\hline No. & \multicolumn{1}{c}{ Variabel } & R-Square \\
\hline 1 & Karakteristik Individu & 0,000 \\
2 & Karakteristik Pekerjaan & 0,000 \\
3 & Kinerja Tenaga Kerja & 0,819 \\
4 & Lingkungan Kerja & 0,000 \\
5 & Motivasi & 0,542
\end{tabular}

Sumber: hasil data primer yang diolah oleh SmartPLS 3.0, 2020.

Pada $R$-Square karakteristik individu, karakterisitk pekerjaan, dan lingkungan kerja terhadap motivasi sebesar 0,542. Ini berarti bahwa karakteristik individu, karakteristik pekerjaan, dan lingkungan kerja memiliki kontribusi positif terhadap motivasi sebesar 54,2\% dan sisanya dipengaruhi oleh faktor lain. Nilai $R$-Square karakteristik individu, karakteristik pekerjaan, dan lingkungan kerja terhadap kinerja tenaga kerja sebesar 0,819. Ini berarti bahwa karakteristik individu, karakteristik pekerjaan, dan lingkungan kerja memiliki kontribusi positif terhadap kinerja tenaga kerja sebesar $81,9 \%$ dan sisanya dipengaruhi oleh faktor lain.

Menurut Chin (1998) dalam Ghoxali (2008) mengatakan bahwa hasil $R$-Square sebesar 0,67, 0,33 , dan 0,19 untuk variabel laten endogen dalam inner model, secara berturut-turut mengindikasikan bahwa model "baik", "moderat" dan "lemah". Berdasarkan teori tersebut dan nilai $R$-Square variabel laten pada penelitian ini menunjukkan bahwa kategori model yang diterangkan termamsuk ke dalam yang baik dan moderat karena nilainya ada diatas 0,67 dan diantara 0,67 dan 0,33. Pengujian hipotesis dilakukan dengan melihat analisis dari bootstraping pada path coefficients, yaitu dengan melakukan perbandingan terhadap nilai $t_{\text {hitung }}$ dengan $t_{\text {tabel }}$. Hasil analisis path coefficients menunjukkan nilai $t_{\text {tabel }}$ yang lebih besar dari 1,96 (dengan selang kepercayaan 95\%) untuk variabel karakteristik individu terhadap kinerja tenaga kerja, karakteristik pekerjaan terhadap motivasi, lingkungan kerja terhadap kinerja tenaga kerja, dan motivasi terhadap kinerja tenaga kerja,

Tabel 6. Nilai Path Coefficients

\begin{tabular}{clc}
\hline No. & \multicolumn{1}{c}{ Variabel } & $\begin{array}{c}\text { Path } \\
\text { Coefficients }\end{array}$ \\
\hline 1 & Karaktenistik Individu $\rightarrow$ Kinerja Tenaga Kerja & 3,251 \\
2 & Karakteristik Individu $\rightarrow$ Motivasi & 0,611 \\
3 & Karakteristik Pekerja an $\rightarrow$ Kinerja Tenaga Kerja & 1,088 \\
4 & Karakteristik Pekerja an $\rightarrow$ Motivasi & 2,144 \\
5 & Lingkungan Kerja $\rightarrow$ Kinerja Tenaga Kerja & 3,374 \\
6 & Lingkungan Kerja $\rightarrow$ Motivasi & 1,803 \\
7 & Motivasi $\rightarrow$ Kinerja Tenaga Kerja & 2,398 \\
\hline
\end{tabular}

\section{Hasil Uji Hipotesis}

1. Hipotesis 1: Karakteristik Individu Berpengaruh Terhadap Motivasi Tenaga Kerja Sukarela Pengumpul Sampah di Dinas Lingkungan Hidup Kabupaten Rejang Lebong. Pada Tabel 6 menunjukkan bahwa karakteristik individu tidak berpengaruh terhadap motivasi, dimana nilai koefisien parameternya sebesar 0,0611 . Hal ini berarti semakin baik karakteristik individu seseorang tidak berpengaruh banyak terhadap motivasi individu tenaga kerja tersebut. Pengujian hipotesis ini ditolak karena pada hasil analisis diperoleh nilai $t_{\text {hitung }} 0,611$ lebih kecil dibanding $\mathrm{t}_{\text {total }} 1,96$. Hal ini menunjukkan bahwa karakteristik individu tenaga kerja pengumpul sampah di Dinas Lingkungan Hidup Kabupaten Rejang Lebong tidak berpengaruh terhadap motivasi tenaga kerja tersebut.

2. Hipotesis 2: Karakteristik Pekerjaan Berpengaruh Terhadap Motivasi Tenaga Kerja Sukarela Pengumpul Sampah di Dinas 
Lingkungan Hidup Kabupaten Rejang Lebong Pada Tabel 6 menunjukkan bahwa karakteristik pekerjaan berpengaruh terhadap motivasi, dimana nilai koefisien parameternya sebesar 0,2144 . Hal ini berarti semakin sesuai karakteristik pekerjaan terhadap individu tenaga kerja dalam melakukan pekerjaan maka motivasi kerja tenaga kerja tersebut akan semakin baik. Pengujian hipotesis ini diterima karena pada hasil analisis diperoleh nilai $t_{\text {hitung }}$ 2,144 lebih besar dibanding $t_{\text {tabel }} 1,96$. Hal ini menunjukkan bahwa karakteristik pekerjaan berpengaruh terhadap motivasi tenaga kerja pengumpul sampah di Dinas Lingkungan Hidup Kabupaten Rejang.

3. Hipotesis 3: Lingkungan Kerja Berpengaruh Terhadap Motivasi Tenaga Kerja Sukarela Pengumpul Sampah di Dinas Lingkungan Hidup Kabupaten Rejang Lebong. Pada Tabel 6 menunjukkan bahwa lingkungan kerja tidak berpengaruh terhadap motivasi, dimana nilai koefisien parameternya sebesar 0,1803 . Hal ini berarti semakin sesuai lingkungan kerja terhadap individu tenaga kerja dalam melakukan pekerjaan tidak berpengaruh banyak terhadap motivasi individu tenaga kerja tersebut. Pengujian hipotesis ini ditolak karena pada hasil analisis diperoleh nilai $t_{\text {hitung }}$ 1,803 lebih kecil dibanding $t_{\text {total }} 1,96$. Hal ini menunjukkan bahwa lingkungan kerja tenaga kerja pengumpul sampah di Dinas Lingkungan Hidup Kabupaten Rejang Lebong tidak berpengaruh terhadap motivasi tenaga kerja tersebut.

4. Hipotesis 4: Karakteristik Individu Berpengaruh Terhadap Kinerja Tenaga Kerja Sukarela Pengumpul Sampah di Dinas Lingkungan Hidup Kabupaten Rejang Lebong. Pada Tabel 6 menunjukkan bahwa karakteristik individu berpengaruh terhadap kinerja tenaga kerja, dimana nilai koefisien parameternya sebesar 0,3251 . Hal ini berarti bahwa semakin sesuai karakteristik individu dalam melakukan pekerjaan maka kinerja tenaga kerja akan semakin baik. Pengujian hipotesis ini diterima karena pada hasil analisis diperoleh nilai $t_{\text {hitung }}$ 3,251 lebih besar dibanding $t_{\text {tabel }} 1,96$. Hal ini menunjukkan bahwa karakteristik individu pada tenaga kerja pengumpul sampah di Dinas Lingkungan Hidup Kabupaten Rejang Lebong berpengaruh terhadap kinerja tenaga kerja.

5. Hipotesis 5: Karakteristik Pekerjaan Berpengaruh Terhadap Kinerja Tenaga Kerja Sukarela Pengumpul Sampah di Dinas Lingkungan Hidup Kabupaten Rejang Lebong. Pada Tabel 6 menunjukkan bahwa karakteristik pekerjaan tidak berpengaruh terhadap kinerja tenaga kerja, dimana nilai koefisien parameternya sebesar 0,1088 . Hal ini berarti semakin sesuai karakteristik pekerjaan terhadap individu tenaga kerja dalam melakukan pekerjaan tidak berpengaruh banyak terhadap kinerja individu tenaga kerja tersebut. Pengujian hipotesis ini ditolak karena pada hasil analisis diperoleh nilai $t_{\text {hitung }} 1,088$ lebih kecil dibanding

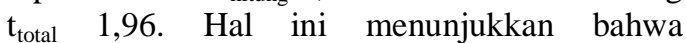
karakteristik pekerjaan tidak berpengaruh terhadap kinerja tenaga kerja pengumpul sampah di Dinas Lingkungan Hidup Kabupaten Rejang.

6. Hipotesis 6: Lingkungan Kerja Berpengaruh Terhadap Kinerja Tenaga Kerja Sukarela Pengumpul Sampah di Dinas Lingkungan Hidup Kabupaten Rejang Lebong. Pada Tabel 6 menunjukkan bahwa lingkungan berpengaruh terhadap kinerja tenaga kerja, dimana nilai koefisien parameternya sebesar 0,3374 . Hal ini berarti semakin sesuai lingkungan kerja terhadap individu tenaga kerja dalam melakukan pekerjaan maka kinerja tenaga kerja tersebut akan semakin baik. Pengujian hipotesis ini diterima karena pada hasil analisis diperoleh nilai $t_{\text {hitung }} 3,374$ lebih besar dibanding $\mathrm{t}_{\text {tabel }} 1,96$. Hal ini menunjukkan bahwa lingkungan kerja tenaga kerja pengumpul sampah di Dinas Lingkungan Hidup Kabupaten Rejang Lebong berpengaruh terhadap kinerja tenaga kerja tersebut.

7. Hipotesis 7: Motivasi berpengaruh terhadap kinerja tenaga kerja sukarela pengumpul sampah di Dinas Lingkungan Hidup Kabupaten Rejang Lebong. Pada Tabel 6 menunjukkan bahwa motivasi berpengaruh terhadap kinerja tenaga kerja, dimana nilai koefisien parameternya sebesar 0,2398. Hal ini berarti semakin baik atau semakin tinggi motivasi tenaga kerja dalam bekerja maka kinerja tenaga kerja tersebut akan semakin baik. Pengujian hipotesis ini diterima karena pada hasil analisis diperoleh nilai $t_{\text {hitung }} 2,398$ lebih besar dibanding $\mathrm{t}_{\text {tabel }} 1,96$. Hal ini menunjukkan bahwa motivasi tenaga kerja pengumpul sampah di Dinas Lingkungan Hidup Kabupaten Rejang Lebong berpengaruh terhadap kinerja tenaga kerja tersebut.

8. Hipotesis 8: Karakteristik individu merupakan faktor yang paling dominan mempengaruhi motivasi dan kinerja tenaga kerja sukarela pengumpul sampah di Dinas Lingkungan Hidup Kabupaten Rejang Lebong. Pada Tabel 6 menunjukkan bahwa yang palilng dominan mempengaruhi motivasi tenaga kerja adalah karakteristik pekerjaan dengan nilai $t_{\text {hitung }} 2,144$ dan yang paling dominan mempengaruhi kinerja tenaga kerja adalah lingkungan kerja dengan nilai $t_{\text {hitung }} 3,374$. Hal ini membuktikan bahwa pengujian hipotesis ini ditolak karena 
karakteristik individu bukan merupakan faktor dominan yang mempengaruhi motivasi dan kinerja tenaga kerja pengumpul sampah di Dinas Lingkungan Hidup Kabupaten Rejang Lebong.

\section{SIMPULAN DAN SARAN}

\section{Simpulan}

Berdasarkan paparan pada bab sebelumnya, maka dapat disimpulkan:

1. Tidak terdapat pengaruh pada karakteristik individu terhadap motivasi kerja tenaga kerja pengumpul sampah di Dinas Lingkungan Hidup Kabupaten Rejang Lebong. Hal ini berarti semakin baik karakteristik individu tenaga kerja maka tidak mempengaruhi motivasi kerja tenaga kerja tersebut.

2. Terdapat pengaruh pada karakteristik pekerjaan terhadap motivasi kerja tenaga kerja pengumpul sampah di Dinas Lingkungan Hidup Kabupaten Rejang Lebong. Hal ini berarti semakin sesuai karakteristik pekerjaan terhadap individu tenaga kerja dalam melakukan pekerjaan maka motivasi kerja tenaga kerja tersebut akan semakin baik.

3. Tidak terdapat pengaruh pada lingkungan kerja terhadap motivasi kerja tenaga kerja pengumpul sampah di Dinas Lingkungan Hidup Kabupaten Rejang Lebong. Hal ini berarti semakin sesuai lingkungan kerja terhadap individu tenaga kerja dalam melakukan pekerjaan maka tidak mempengaruhi motivasi kerja tenaga kerja tersebut.

4. Terdapat pengaruh pada karakteristik individu terhadap kinerja tenaga kerja pengumpul sampah di Dinas Lingkungan Hidup Kabupaten Rejang Lebong. Hal ini berarti semakin baik karakteristik individu tenaga kerja maka kinerja tenaga kerja tersebut akan semakin baik.

5. Tidak terdapat pengaruh pada karakteristik pekerjaan terhadap kinerja tenaga kerja pengumpul sampah di Dinas Lingkungan Hidup Kabupaten Rejang Lebong. Hal ini berarti semakin sesuai karakteristik pekerjaan terhadap individu tenaga kerja dalam melakukan pekerjaan maka tidak mempengaruhi kinerja tenaga kerja tersebut.

6. Terdapat pengaruh pada lingkungan kerja terhadap kinerja tenaga kerja pengumpul sampah di Dinas Lingkungan Hidup Kabupaten Rejang Lebong. Hal ini berarti semakin sesuai lingkungan kerja terhadap individu tenaga kerja dalam melakukan pekerjaan maka kinerja tenaga kerja tersebut akan semakin baik.
7. Terdapat pengaruh pada motivasi terhadap kinerja tenaga kerja pengumpul sampah di Dinas Lingkungan Hidup Kabupaten Rejang Lebong. Hal ini berarti semakin baik atau semakin tinggi motivasi kerja tenaga kerja maka kinerja tenaga kerja tersebut akan semakin baik pula.

8. Faktor yang paling dominan mempengaruhi motivasi kerja tenaga kerja pengumpul sampah di Dinas Lingkungan Hidup adalah karakteristik pekerjaan, sedangkan faktor yang paling dominan mempengaruhi kinerja tenaga kerja pengumpul sampah di Dinas Lingkungan Hidup adalah lingkungan kerja.

9. Beberapa hal yang perlu diperhatikan untuk menjaga, mempertahankan, dan/atau meningkatkan motivasi dan kinerja tenaga kerja sukarela pengumpul sampah, diantaranya yaitu: perlunya edukasi atau arahan kepada tenaga kerja mengenai sampah sehingga mereka bisa memimliki keterampilan dalam berbicara atau mengajak masyarakat sekitar untuk tidak membuang sampah secara sembarangan dan mengumpulkan sampah kedalam wadah (karung) sehingga pengambilan atau pengumpulan sampah menjadi lebih efektif dan efisien dan pekerjaan mereka dalam mengumpulkan sampah dapat terlaksana dengan baik, perlunya briefing atau arahan mengenai pekerjaan yang harus dikerjakan dan diselesaikan kepada para tenaga kerja, perlunya evaluasi rutin terhadap hasil kerja atau kinerja tenaga kerja, perlunya pengaturan jadwal pengumpulan sampah yang sesuai dengan kondisi lingkungan sekitar sehingga pengumpulan sampah dapat berjalan dengan efektif, para pekerja harus mematuhi SOP dan menggunakan APD secara lengkap, perlunya pembagian tugas secara adil, dan menjaga komunikasi yang baik dengan para tenaga kerja.

\section{Saran}

Saran yang dapat disampaikan dari penelitian ini yaitu:

1. Saran Bagi Instansi. Berikut ini beberapa saran yang penulis berikan bagi Instansi terkait: a) Perlunya perhatian dari Instansi terkait dalam hal ini Dinas Lingkungan Hidup Kabupaten Rejang Lebong untuk dapat memperhatikan variabel-variabel atau faktor-faktor yang secara signifikan mempengaruhi motivasi dan kinerja tenaga kerja agar motivasi dan kinerja yang baik dapat dipertahankan atau ditingkatkan. b) Perlunya pemberdayaan program pengembangan SDM dengan tujuan memberikan penyegaran maupun kesiapan diri tenaga kerja dalam menghadapi segala 
perubahan yang dapat terjadi baik perubahan yang berasal dari instansi itu sendiri dalam hal ini Dinas Lingkungan Hidup Kabupaten Rejang Lebong maupun dari luar instansi seperti kebijakan pemerintah dan lingkungan tempat bekerja.

2. Saran Bagi Penelitian Selanjutnya. Berikut ini beberapa saran yang penulis berikan bagi peneliti selanjutnya: a) Penulis menyarankan untuk peneliti selanjutnya agar dapat meneliti pengaruh karakteristik individu, karakteristik pekerjaan, dan lingkungan kerja terhadap motivasi dan kinerja tenaga kerja sukarela lain seperti penyapu jalan di Dinas Lingkungan Hidup Kabupaten Rejang Lebong ini. b) Bagi peneliti selanjutnya yang tertarik untuk melakukan penelitian serupa tersebut, agar dapat mempertimbangkan adanya faktor-faktor atau variabel lain selain karakteristik individu, karakteristik pekerjaan, dan lingkungan kerja yang mungkin akan mempengaruhi motivasi dan kinerja tenaga kerja, seperti faktor budaya organisasi atau instansi dan lain-lain.

\section{DAFTAR PUSTAKA}

Abdul Rahman. (2013). Pengaruh Karakteristik Individu, Motivasi dan Budaya Kerja Terhadap Kinerja Pegawai Pada Badan Keluarga Berencana dan Pemberdayaan Perempuan Kabupaten Donggala.

Aktarina, Destria. (2015). Pengaruh Karakteristik Individu, Pekerjaan dan Lingkungan Kerja Terhadap Motivasi dan Dampaknya Terhadap Kinerja Anggota Polresta Palembang.

Andriyansah, dkk. (2019). Pengaruh Gaya Kepemimpinan, Budaya Kerja, Motivasi terhadap Disiplin Kerja serta Dampaknya terhadap Kemampuan Kerja Pegawai dan Kinerja di Puskesmas Se-Kota Pangkalpinang.

Andriyansah, dkk. (2020). The Effect of Work Discipline and Work Motivation Towards The Performances od LPP RRI Employees.

Basalamah, Muhammad Syafi'i. (2017). The Influence of Motivation, Competence and Individual characteristics on Performance clerk (The Study) in The City od Makassar.

Ghaffari, Sara, dkk. (2017). The Influence of Motivation on Job Performance: A Case Study at Universiti Teknologi Malaysia.

Hayati, Nur dan Imelda Cristina Sinaga. (2014). Pengaruh Karakteristik Individu (Individual Characteristic) dan Karakteristik Tim (Characteristics Team) Terhadap Kinerja Tim (Performance Team) (Studi pada karyawan bagian marketing PT. Srikandi.
Kurniawati. (2014). Pengembangan Sumber Daya Manusia (PSDM). In: Peranan Strategis Pengembangan SDM dalam Manajemen SDM. Tangerang Selatan: Universitas Terbuka.

Malayu S.P, Hasibuan. (2017). Manajemen Sumber Daya Manusia. Jakarta: PT Bumi Aksara.

Mangkunegara, A.A. Anwar Prabu. (2010). Manajemen Sumber daya Manusia Perusahaan. Bandung: PT Remaja Rosdakarya.

Mangkunegara, A.A. Anwar Prabu. (2011). Manajemen Sumber daya Manusia Perusahaan. Bandung: PT Remaja Rosdakarya.

Munandar, Risto, dkk. (2019). Effect of Individual Characteristics, Work Environment, and Work Motivation on Performance of Madrasah Teachers.

Panggabean, Mutiara Sibarani. (2016). Manajemen Sumber Daya Manusia (Edisi 2). Tangerang Selatan: Univertitas Terbuka.

Pujiwai, Ami dan Etty Susanty. (2014). The Influence of Individual Characteristics and Work Motivation on Employee Performance (Local Government of West Java).

Sedarmayanti. (2011). Manajemen Sumber Daya Manusia. Reformasi Birokrasi dan Manajemen Pegawai Negeri Sipil. Cetakan Kelima. Bandung: PT Refika Aditama.

Sobiri, Achmad. (2014). Manajemen Kinerja. Tangerang Selatan: Universitas Terbuka.

Stoner, James AF dan R Edward Freeman. (1994). Manajemen Edisi Kelima. Jilid 2. Jakarta: Intermedia.

Subyantoro, Arief. (2010). Karakteristik Individu, Karakteristik Pekerjaan, Karakteristik Organisasi Dan Kepuasan Yang dimediasi Oleh Motivasi Kerja, Jurnal Aplikasi Manajemen, 11(1), 11-19.

Sugiyono. (2008). Metode Penelitian Kuantitatif Kualitatif dan R \& D. Bandung: Alfabeta.

Sugiyono. (2012). Metode Penelitian Kuantitatif Kualitatif dan R \& D. Bandung: Alfabeta.

Sumantri, dkk. (2017), The Effect of Individual Characteristics, Competence and Quality of Work Life on Work Motivation, Intention to Leave and Employee Performance Outsoursing Manufacturing Company in East Java Province. 
Sunuharyo, Bambang Swanto dan Sella Selvia Ananda. (2018). Pengaruh Karakteristik Individu dan Karakteristik Pekerjaan Terhadap Kinerja Karyawan dengan Variabel Mediator Motivasi Kerja Karyawan (Studi pada Karyawan PT. PETROKIMIA GRESIK).

Sunyoto, Danang. (2012). Manajemen Sumber Daya Manusia. Jakarta: PT Buku Seru.

Sutrisno, Edy. (2010). Manajemen Sumber Daya Manusia. Jakarta: Kencana.

Utaminingsih, Alifiulahtin. (2018). Karakteristik Individu, Karakteristik Pekerjaan dan Pengalaman Kerja, Pengaruhnya Terhadap Kemampuan, Motivasi dan Kinerja Dosen Tetap Fisip Universitas Brawijaya Malang.

Wibowo. (2010). Manajemen Kinerja. Jakarta: Rajawali Press. 